\title{
Relationship between 25-Hydroxyvitamin D Content and Quality Characteristics and Lipid Oxidation in Raw and Cooked Camel Meat during Cold Storage
}

\author{
RababTabite \\ Abdelilah Lemrhamed \\ Mohammed El Khasmi \\ Laboratory of Physiopathology and Molecular Genetics \\ Faculty of Sciences Ben M'Sik \\ University Hassan II of Casablanca \\ PB 7955 SidiOthmane, Casablanca \\ Morocco \\ Najia El Abbadi \\ Unit of Radio-Immuno-Analysis \\ Division of Life Sciences \\ National Center for Energy \\ Science and Nuclear Techniques \\ PB 1382 RP 10001, Rabat \\ Morocco \\ Abderrahmane Belhouari \\ Laboratory of Ecology and Environment \\ Faculty of Sciences Ben M'Sik \\ University Hassan II of Casablanca \\ PB 7955 SidiOthmane, Casablanca \\ Morocco \\ Bernard Faye \\ FAO/CIRAD-ES \\ Campus International de Baillarguet \\ TA 112/B, UMR Selmet 34398 Montpellier \\ France
}

\begin{abstract}
In camel, 25-hydroxyvitamin D content, quality parameters and lipid oxidation in raw and cooked meat during ageing at cold, and relationship between these parameters were investigated. The $\mathrm{pH}$ value of the raw meat was significantly $(P<0.05)$ lower from the day 3 postmortem, and $C L$ was maintained significantly $(P<0.05)$ higher from the day 5 postmortem. Compared to raw meat, cooked meat levels of MDA (umoles/Kg) were significantly very higher $7 \mathrm{~d}$ and 10 $d$ postmortem.In raw and cooked meat, the content of 25-OH-D showed no significant variation during all postmortem ageing times. However, cooked meat showed a significant $(P<0.05)$ increase of 25-OH-D levels by comparison to raw meat.In both raw and cooked meat, 25-OH-D levels were negatively correlated with those of MDA, DL and CL, and those of MDA were positively correlated with DL and CL. During cold ageing, raw and cooked meat was subjected to a water loss and lipid peroxidation without significant alteration of 25-OH-D content. This metabolite may be implicated in antioxidant status of camel meat.
\end{abstract}

Keywords: Camel, cold storage, meat quality, 25-hydroxyvitamin D, lipid oxidation

\section{Introduction}

Camel meat is known to be beneficial for health because of its low fat and cholesterol contents (Kadim et al., 2006), but it is rich in myoglobin, otherheme compounds and polyunsaturated fatty acids that could act as pro-oxidants resulting in oxidation of lipids (Maqsood and Benjakul, 2011). 
Lipid oxidation of meat starts just after the slaughter of the animal and induces degradation of fat-soluble vitamins and essential fatty acids (Kanner, 2007). In addition, treatment of meat by cooking or cold storage improves its quality but may also lead to the oxidation of its lipids and proteins and impact its nutritional and sensory qualities (Hur et al. 2004). Among the compounds of camel meat, 25-hydroxyvitamin D (25-OH-D) is found at concentrations similar to those of other livestock, which could be a significant source of this vitamin for the populations of desert regions (El khasmi et al. 2013, Bargaâ et al., 2015; Tabite et al., 2018). In the camel, a postmortem ageing time of meat for 10 days at $4^{\circ} \mathrm{C}$, influenced significantly its quality characteristics and antioxidant status without any variation of its 25-OH-D content. Vitamin D was found able to impact the composition, size, function, metabolism and growth of the skeletal muscle (Ceglia and Harris, 2013). In addition, it was reported that dietary vitamin D3 supplementation increased ultimate $\mathrm{pH}$, water holding capacity (Wilborn et al. 2004) and antioxidant activity (Duffy et al., 2018) in meat. In the present study, a potential relationship between 25-OH-D content and quality characteristics ( $\mathrm{pH}$, moisture, ashes, drip loss, cooking loss) and lipid oxidation (malondialdehyde) in raw and cooked camel meat during cold storage was investigated.

\section{Materials and methods}

\subsection{Animals}

Our study was conducted on 5 camels (Camelusdromedarius) male and female, apparently healthy, 5 to 14 years old and weighing 180 to $390 \mathrm{Kg}$. They were intended for slaughter at the municipal slaughterhouse of Casablanca in the West of Morocco (North of Africa, latitude 33³4'42.44” N, longitude 7³6’23.89” O). All camels were transported by truck for 72 to $80 \mathrm{~km}$ at an average $60-65 \mathrm{~km} / \mathrm{h}$ speed, and the stocking density was $2.6 \mathrm{~m}^{2} / \mathrm{camel}$. The transportation vehicles did not have ceilings or roof coverings, and its floor and surrounding walls were made of iron. The camels were transported without any bedding materials, feed deprived overnight and transported in a side-facing position and squatting position holding the forelegs tight by a rope at the knees. During transportation, the camels could not feed and drink, and the road was asphalted until the arrival to the slaughterhouse. They were carefully unloaded on arrival at the abattoir to avoid stress and were calmly guided into the waiting station. On arrival at the slaughterhouse, after unloading, camels were placed in the waiting station and were subjected to a rest period for 13 to 18 hs at a stocking density of $4 \mathrm{~m}^{2} /$ camel without access to water and food, and without isolating them from noise and human activity. Following the rest period, the animals were guided inside the slaughter roomat 7:00 am, to be slaughtered according to the routine Halalprocedure without any prior stunning. They were placed in a squatting position on the floor with the forelegs tied with a rope at the knees. The head was fixed in a caudal position (ie turned towards the tail) and then a quick cut with a sharp knife between the base of the neck and the thorax, quickly bleed the animals by section of the jugular veins, carotid arteries, trachea and esophagus in one stroke without severing the spinal cord by an adult Muslim. The animals were hung to remove the skin, head, fore feet, hind feet, gastrointestinal tract and viscera organs. Carcasses were chilled under commercial conditions at $4^{\circ} \mathrm{C}$ for $12 \mathrm{~h}$ in total darkness.

\subsection{Muscle removal}

After slaughtering and veterinary inspection, approximately $450 \mathrm{~g}$ of abdominal external muscle (musculusabdominisobliquusexternus) was cut at 10 a.mwithin $3 \mathrm{~h}$ postmortem from the right side of carcasses of each animal. These samples were packaged in zipped plastic bags and transported for $15 \mathrm{~min}$ in an insulated cool box, from the slaughterhouse to our laboratory at the Ben M'Sik Faculty of Sciences in Casablanca. All knives - separable fat and connective tissue of the muscle were removed and the lean meat samples were divided into 2 portions of $225 \mathrm{~g}$, one was kept raw and the other was cooked. The raw and cooked portions were cut into 5 portions of $45 \mathrm{~g}$ : P0d ( $3 \mathrm{hs}$ ), P3d, P5d, P7d and P10d which were packaged separately in plastic bags and kept in a refrigerator $\left(4 \pm 1^{\circ} \mathrm{C}\right)$ for $3 \mathrm{~h}$ postslaughter (d0), 3d, 5d, 7d and 10days postmortemrespectiveley. Each raw and cooked portion was divided into 4 parts: p1 (5g) to analyze 25-OH-D, p2 (5g) to analyze moisture and ashes, p3 (30 g) to analyze pH, DL and CL and p4 ( $5 \mathrm{~g})$ to estimate MDA, at each postmortem ageing time. These parts were packaged separately in a sterile polythene bags, labelled and then were stored in the refrigerator at $4 \pm 1^{\circ} \mathrm{C}$ during its corresponding ageing time.

To analyze MDA and 25-OH-D at different ageing times, meat samples were ground then homogenized in the presence of a phosphate buffer solution $(0.1 \mathrm{M}, \mathrm{pH} 7.4)$ and acetonitrile respectively. Thereafter, homegenates were stored at $80^{\circ} \mathrm{C}$ until dosage.

\subsection{Cooking meat}

Meat was cookedwithout adding ingredients or fat in the Silex clam-cooker set at $200^{\circ} \mathrm{C}$ to an internal temperature of $72^{\circ} \mathrm{C}$ for 30 minutes. The internal temperature was monitored using a thermometer. The internal temperature during boiling was $97^{\circ} \mathrm{C}$. After cooking, the samples were cooled to ambient $\mathrm{T}^{\circ}$.

\subsection{Moisture and ashes analysis}


Moisture, dry matter and ashes were determined according to the standard methods of Association of Official Analytical Chemists (AOAC 2000). Moisture tissue was determined by desiccation in an oven at $105^{\circ} \mathrm{C}$ for $24 \mathrm{~h}$ until a constant weight. Then the meat samples were incinerated in a muffle furnace $\left(2 \mathrm{~h}\right.$ at $\left.600^{\circ} \mathrm{C}\right)$ to determine the total ashes concentration.

\section{5. pH measurement}

The extent of muscle $\mathrm{pH}$ was performed directly using a $\mathrm{pH}$ meter with a spear-type electrode on the extracted meat samples crushed and homogenized using a porcelain mortar.Two g of muscle sample were homogenized with $20 \mathrm{~mL}$ neutralized 5-mM sodium iodoacetate. The $\mathrm{pH}$ meter was calibrated with $\mathrm{pH} 4$ and 7 standards, and the $\mathrm{pH}$ value was measured at $18-20^{\circ} \mathrm{C}$ using a standardized glass electrode attached to digital $\mathrm{pH}$ meter.

\subsection{Drip loss}

Drip loss (DL) was expressed as percentage of weight loss after cold storage and was calculated from the difference in muscle weight before and after ageing, using the method of Pohja and Niinivaara (1957) with some modifications. Meat samples weighing $5 \mathrm{~g}$ were placed between two Whatman No. 1 filter papers and pressed at $10 \mathrm{~kg}$ for $5 \mathrm{~min}$. Then, meat samples were separated from the filter papers and reweighed. The DL was expressed as percentage of weight loss after cold storage and was calculated from the difference in muscle weight before and after ageing using the following formula: [(initial sample weight - final weight $) /$ initial sample weight $] \times 100$.

\subsection{Cooking loss}

The cooking losse (CL) was calculatedas the percentage of the weight of the cooked samples compared to the weight of the raw samples, using the method of Honikel (1998). Meat $(30 \mathrm{~g})$ was placed in polyethylene bag and totally immersed without adding ingredients or fat in a water bath at $70^{\circ} \mathrm{C}$ for $90 \mathrm{~min}$. The internal temperature monitored using a thermometer during boiling was $97^{\circ} \mathrm{C}$. After cooking, the samples were cooled to room temperature for $40 \mathrm{~min}$ in its exuded fluids and then removed and dried slightly with blotting paper and reweighed. CL (\%) was calculated as the difference in the sample mass before and after cooking, expressed as a percentage of the initial sample mass: CL $(\%)=[($ initial sample weight - final weight $) /$ initial weight $] \times 100$.

\subsection{Malondialdehyde analysis}

The malondialdehyde (MDA) assay was performed by the method of Ohkawa et al. (1979). This test is based on the formation of acid and heat medium $\left(100^{\circ} \mathrm{C}\right)$ between MDA (marker of lipid oxidation) and thiobarbituric acid (TBA) an absorbent colored pigment at $530 \mathrm{~nm}$, extrac table by organic solvents such as butanol. Half a $\mathrm{mL}$ of the homogenate having been prepared from a sample of $5 \mathrm{~g}$ was mixed with $0.5 \mathrm{ml}$ of trichloroacetic acid (TCA) $20 \%$ and $1 \mathrm{ml}$ of thiobarbituric acid (TBA) $0.67 \%$, then incubated in a water bath at a temperature of $100^{\circ} \mathrm{C}$ for 15 minutes. After cooling, $4 \mathrm{ml}$ of n-butanolwas added to the mixture and then centrifuged for 15 minutes at $3000 \mathrm{rpm}$. And finally, the optical density of the supernatant was measured at a wavelength equal to 530nm against the blank. The concentration of MDA was calculated according to the formula: $\mathrm{C}=103 \mathrm{OD} / \varepsilon \chi \mathrm{LD}(3)$ where $\mathrm{C}$ : concentration of $\mathrm{MDA}$ in $\mu \mathrm{mol} / \mathrm{mL}$; OD: optical density read at $530 \mathrm{~nm}$; $\varepsilon$ : molar extinction coefficient of the MDA $=1.56 \times 10^{5} / \mathrm{M} / \mathrm{cm}$; L: optical path length $=0.779 \mathrm{~cm} ; \chi$ : volume of the sample $(\mathrm{mL})$; $\mathrm{D}$ : dilution factor.

\subsection{Analysis of 25-hydroxyvitamin $D$}

Meat samples $(2 \mathrm{~g})$ were cut into thin slices, homogenized then extracted with $2.5 \mathrm{ml}$ of acetonitrile diluted with distilled water $(10 \mathrm{v} / 4 \mathrm{v})$ for $3 \mathrm{~h}$. The samples were shaken vigorously every $30 \mathrm{~min}$ to facilitate extraction. Thereafter, the extracts obtained were centrifuged for $5 \mathrm{~min}$ at $4000 \mathrm{rpm}$ and the supernatant was aliquoted and stored at $-80^{\circ} \mathrm{C}$ until analysis of 25-OH-D3 using a radioimmunoassay kits (Biosource Europe SA., Belgium; Product KIP1961). These kits using ${ }^{125}$ I radio-labelled 25-OH-D proved efficient in previous experiments in camel meat (El Khasmi et al. 2013, Bargaâ et al., 2015; Tabite et al., 2018). The areas of validation for 25-OH-D assays included limits of detection, and precision in the standard curve following sample dilution, inter- and intra-assay coefficients of variation results were considered.

\subsection{Statistical Analysis}

Data were analyzed using analysis of variance (ANOVA) of the General Linear Models procedure of the Statistical Analysis System software (SAS, 2005). Duncan's multiple range test was used to determine if significant differences existed among ageing times. $\mathrm{P}<0.05$ was considered as the level of significance. The degree to which variables were related was measured with Pearson's correlation.

\section{Results}

\subsection{Moisture and ashes}


During cold storage, moisture and ashes (Table 1) in raw and cooked meat of the camel showed no significant variation during all storage times. These parameters showed no significant differences between raw and cooked meat. So, moisture was respectively $73.78 \pm 2.82$ vs $23.31 \pm 1.44$ on day 3 postmortem storage, and $73.73 \pm 3.13$ vs $74.14 \pm 3.49$ on day 7, however, ashes were respectively $1.14 \pm 0.08 v s 1.26 \pm 0.08$ on day 3 postmortem storage, and $1.244 \pm 0.08 v s 1.21 \pm 0.08$ on day 7 (Table 1).

Table 1- Effect of cold storage at $4{ }^{\circ} \mathrm{C}$ on moisture, ashes, $\mathrm{pH}$, drip loss (DL) cooking loss (CL), malondialdehyde (MDA) and 25-hydroxyvitamin D (25-OH-D) in raw and cooked meat of the camel(Mean $\pm \mathrm{SEM},{ }^{\mathrm{a}} \mathrm{P}<0.05,{ }^{\mathrm{aa}} \mathrm{P}<0.005$, comparison with $3 \mathrm{~h}$ postmortem stage (day 0 ) for each type of meat; ${ }^{\mathrm{b}} \mathrm{P}<0.05,{ }^{\mathrm{bb}} \mathrm{P}<0.005$, comparison between raw and cooked meat at the same stages).

\begin{tabular}{lllllll}
\hline & Storage days & $\left.\mathbf{d}_{\mathbf{0}} \mathbf{( 3 h}\right)$ & $\mathbf{d}_{\mathbf{3}}$ & $\mathbf{d}_{\mathbf{5}}$ & $\mathbf{d}_{\mathbf{7}}$ & $\mathbf{d}_{\mathbf{1 0}}$ \\
\hline $\begin{array}{l}\text { Moisture } \\
(\%)\end{array}$ & Raw meat & $75.38 \pm 2.68$ & $73.78 \pm 2.82$ & $74.32 \pm 3.09$ & $73.73 \pm 3.13$ & $73.86 \pm 2.89$ \\
\cline { 2 - 7 } $\begin{array}{l}\text { Ashes } \\
(\%)\end{array}$ & Cooked meat & $74.58 \pm 3.03$ & $73.78 \pm 3.54$ & $74.29 \pm 3.64$ & $74.14 \pm 3.49$ & $73.66 \pm 3.30$ \\
\hline Raw meat & $1.12 \pm 0.08$ & $1.14 \pm 0.08$ & $1.194 \pm 0.09$ & $1.244 \pm 0.08$ & $1.25 \pm 0.09$ \\
\hline pH & Cooked meat & $1.20 \pm 0.09$ & $1.26 \pm 0.08$ & $1.11 \pm 0.08$ & $1.21 \pm 0.08$ & $1.24 \pm 0.08$ \\
\hline $\begin{array}{l}\text { DL } \\
(\%)\end{array}$ & Raw meat & $6.42 \pm 0.11$ & $5.59 \pm 0.10^{\mathrm{a}}$ & $5.60 \pm 0.11^{\mathrm{a}}$ & $5.74 \pm 0.12^{\mathrm{a}}$ & $5.73 \pm 0.12^{\mathrm{a}}$ \\
\hline CL $(\%)$ & Raw meat & $1.90 \pm 0.01$ & $1.87 \pm 0.08$ & $2.34 \pm 0.09^{\mathrm{a}}$ & $2.34 \pm 0.06^{\mathrm{a}}$ & $2.18 \pm 0.06^{\mathrm{a}}$ \\
\hline MDA & Cooked meat & $1.89 \pm 0.07$ & $1.94 \pm 0.05$ & $2.37 \pm 0.06^{\mathrm{a}}$ & $2.39 \pm 0.04^{\mathrm{a}}$ & $2.20 \pm 0.05^{\mathrm{a}}$ \\
$(\mu \mathrm{\mu moles} / \mathrm{Kg})$ & Raw meat & $21.38 \pm 1.64$ & $23.31 \pm 1.44$ & $25.97 \pm 1.88^{\mathrm{a}}$ & $30.52 \pm 1.84^{\mathrm{a}}$ & $32.61 \pm 1.81^{\mathrm{a}}$ \\
\hline $\begin{array}{lllll}\text { 25-OH-D } \\
(\mathrm{ng} / \mathrm{g})\end{array}$ & Raw meat & $0.14 \pm 0.03$ & $0.3 \pm 0.06^{\mathrm{a}}$ & $0.43 \pm 0.08^{\mathrm{aa}}$ & $0.56 \pm 0.05^{\mathrm{aa}}$ & $0.70 \pm 0.07^{\mathrm{aa}}$ \\
\cline { 2 - 7 } & Raw meat & $3.39 \pm 1.47$ & $2.94 \pm 0.69$ & $2.97 \pm 0.77$ & $2.99 \pm 0.81$ & $3.89 \pm 0.91$ \\
\hline
\end{tabular}

\section{2. $\mathrm{pH}$}

Compared to stage $3 \mathrm{~h}$ of cold storage, $\mathrm{pH}$ of the raw meat was significantly $(\mathrm{P}<0.05)$ lower from the day 3 postmortem (6.42 $\pm 0.11 v s 5.59 \pm 0.10$, respectively) and was kept low until the day $10(5.73 \pm 0.12)$ (Table 1).

\subsection{Drip loss}

During cold storage of raw and cooked meat, DL $(\%)$ increased significantly $(\mathrm{P}<0.05)$ since the $5^{\text {th }}$ postmortem day by comparison to 3 hs postlaughter (d0) (2.34 \pm 0.09 vs $1.90 \pm 0.01$ and $2.37 \pm 0.06$ vs $1.89 \pm 0.07$ respectively). Compared to raw meat, DL in cooked meat showed no significant differences during all postmortem ageing times (Table 1).

\subsection{Cooking loss}

CL of the camel meat was maintained significantly $(\mathrm{P}<0.05)$ higher from the day 5 postmortem than that observed on the $3^{\text {rd }}$ postslaughter hour $(25.97 \pm 1.88$ vs $21.38 \pm 1.64)$ and was kept high until 10 days postmortem $(32.61 \pm 1.81)$ (Table 1).

\subsection{Malondialdehyde}

During cold ageing of raw and cooked meat, MDA levels $(\mu$ moles $/ \mathrm{Kg})$ were significantly $(\mathrm{P}<0.05)$ higher on the $3^{\text {rd }}$ postmortem day $(0.3 \pm 0.06$ and $0.49 \pm 0.08$, respectively) and significantly $(\mathrm{P}<0.005)$ very higher $(0.56 \pm 0.05$ and $0.89 \pm 0.03$, respectively) than those measured on day $0(0.14 \pm 0.03$ and $0.15 \pm 0.02$, respectively) (Table 1). Compared to raw meat, cooked meat levels of MDA $(\mu$ moles $/ \mathrm{Kg})$ were significantly very higher at $7 \mathrm{~d}(0.56 \pm 0.05 v s 0.89 \pm 0.03$, $\mathrm{P}<0.005)$ and $10 \mathrm{~d}(0.70 \pm 0.07$ vs $1.19 \pm 0.07, \mathrm{P}<0.005)$ postmortem (Table 1).

\subsection{5-hydroxyvitamin D}

In raw and cooked meat of the camel, the content of 25-OH-D showed no significant variation during all storage times (Table 1). However, compared to raw meat, cooked meat showed a significant $(\mathrm{P}<0.05)$ increase of $25-\mathrm{OH}-\mathrm{D}$ levels during ageing (2.94 $\pm 0.69 v s 6.18 \pm 2.36$, respectively on the $3^{\text {rd }}$ day and $2.99 \pm 0.81$ vs $5.16 \pm 1.55$, respectively on the $7^{\text {th }}$ day) (Table 1).

\subsection{Correlations between studied parameters}

As showed in tables 1 and 2, the 25-OH-D levels were negatively correlated with those of MDA, DL and CL, and those of MDA were positively correlated with DL and CL in raw (Table 2) and cooked (Table 3) meat of camel. 
Table 2. Correlation between 25-hydroxyvitamin D (25-OH-D), pH, moisture, ashes, drip loss (DL), cooking loss (CL) and malondialdehyde (MDA) during ageing of raw meat at $4{ }^{\circ} \mathrm{C}$ during 10 posmortem days in the camel.

\begin{tabular}{|l|l|l|l|l|l|l|}
\hline & \multicolumn{1}{|c|}{$\mathrm{pH}$} & Moisture & \multicolumn{1}{c|}{ Ashes } & \multicolumn{1}{c|}{$\mathrm{DL}$} & $\mathrm{CL}$ & MDA \\
\hline 25-OH-D & $\mathrm{r}=0.397$ & $\mathrm{r}=0.259$ & $\mathrm{r}=-0.559$ & $\mathrm{r}=-0.457$ & $\mathrm{r}=-0.650$ & $\mathrm{r}=-0.682$ \\
& $\mathrm{P}=0.049$ & $\mathrm{P}=0.2112$ & $\mathrm{P}=0.0037$ & $\mathrm{P}=0.0217$ & $\mathrm{P}=0.0004$ & $\mathrm{P}=0.0001$ \\
\hline $\mathrm{pH}$ & & $\mathrm{r}=0.461$ & $\mathrm{r}=-0.509$ & $\mathrm{r}=-0.405$ & $\mathrm{r}=-0.327$ & $\mathrm{r}=-0.508$ \\
& & $\mathrm{P}=0.0204$ & $\mathrm{P}=0.0092$ & $\mathrm{P}=0.0443$ & $\mathrm{P}=0.1104$ & $\mathrm{P}=0.0095$ \\
\hline Moisture & & & $\mathrm{r}=-0.813$ & $\mathrm{r}=-0.048$ & $\mathrm{r}=0.175$ & $\mathrm{r}=-0.053$ \\
& & & $\mathrm{P}=0.0000$ & $\mathrm{P}=0.8209$ & $\mathrm{P}=0.4033$ & $\mathrm{P}=0.8001$ \\
\hline Ashes & & & & $\mathrm{r}=0.466$ & $\mathrm{r}=0.290$ & $\mathrm{r}=0.467$ \\
& & & & $\mathrm{P}=0.0188$ & $\mathrm{P}=0.1600$ & $\mathrm{P}=0.0184$ \\
\hline DL & & & & & $\mathrm{r}=0.639$ & $\mathrm{r}=0.678$ \\
& & & & & $\mathrm{P}=0.0005$ & $\mathrm{P}=0.0002$ \\
\hline CL & & & & & & $\mathrm{r}=0.930$ \\
& & & & & & $\mathrm{P}=0.0000$ \\
\hline
\end{tabular}

Table 3. Correlation between 25-hydroxyvitamin D (25-OH-D), moisture, ashes, drip loss (DL) and malondialdehyde (MDA) during ageing of cooked meat at $4^{\circ} \mathrm{C}$ during 10 posmortem days in the camel.

\begin{tabular}{|c|c|c|c|c|}
\hline & 25-OH-D & Moisture & Ashes & $\mathrm{CL}$ \\
\hline MDA & $\begin{array}{l}\mathrm{r}=-0.847 \\
\mathrm{P}=0.0000\end{array}$ & $\begin{array}{l}\mathrm{r}=0.045 \\
\mathrm{P}=0.8322\end{array}$ & $\begin{array}{l}\mathrm{r}=0.034 \\
\mathrm{P}=0.8707\end{array}$ & $\begin{array}{l}\mathrm{r}=0.726 \\
\mathrm{P}=0.0000\end{array}$ \\
\hline $25-\mathrm{OH}-\mathrm{D}$ & & $\begin{array}{l}\mathrm{r}=0.166 \\
\mathrm{P}=0.4279\end{array}$ & $\begin{array}{l}\mathrm{r}=-0.157 \\
\mathrm{P}=0.4531\end{array}$ & $\begin{array}{l}\mathrm{r}=-0.664 \\
\mathrm{P}=0.0003\end{array}$ \\
\hline Moisture & & & $\begin{array}{l}\mathrm{r}=-0.806 \\
\mathrm{P}=0.0000\end{array}$ & $\begin{array}{l}\mathrm{r}=0.034 \\
\mathrm{P}=0.8724\end{array}$ \\
\hline Ashes & & & & $\begin{array}{l}\mathrm{r}=0.112 \\
\mathrm{P}=0.5930\end{array}$ \\
\hline
\end{tabular}

\section{Discussion}

In the work reported here, variation of 25-OH-D content, quality parameters and lipid oxidation in raw and cooked meat during refrigerated ageing for ten days, and relationship between these parameters were studied in the dromedary camel. A significant decrease of $\mathrm{pH}$ in raw meat and a significant increased DL, CL and lipid peroxidation in raw and cooked meat, without significant differences in postmortem 25-OH-D contents were observed. However, in cooked meat, MDA and 25-OH-D were significantly higher than those observed in raw meat.

In the dromedary camel, the postmortem $\mathrm{pH}$ and quality parameters of meat, could be impacted by the preslaughter stress conditions, such as transport distance (El khasmi et al., 2015), loading density (Lemrhamed et al., 2018), waiting period (Lemrhamed et al., 2019a), and the slaughter procedure used at the abattoir (Lemrhamed et al., 2019b). These factors are responsible for activation of the hypothalamic-pituitary-adrenal axis (HPA) (Swanson and Morrow-Tesch, 2001), inducting welfare violations and degradation of meat quality (Teke et al., 2014; Kober et al., 2014), leading to altered water holding capacity (WHC), tenderness and flavor during meat ageing (Ferguson and Warner 2008).

The quality of meat is often described by meat $\mathrm{pH}$ at different timespostmortem, as well as by DL. In addition, rapid postmortem $\mathrm{pH}$ decline while muscle temperature is still high causes denaturation of many proteins, including those involved in binding water (Offer and Knight, 1988). It is currently admitted that fasting time during lairage at the abattoir may induce depletion of muscular glycogen reserves prior to slaughter leading to an increase of $\mathrm{pHu}$ and DL in meat (Terlouw and Rybarzcyk, 2008; Salmi et al., 2012). On another hand, postmortem $\mathrm{pH}$ and temperature kinetics influence the rate and extent of protein denaturation, oxidation and proteolysis, lipid oxidation which in turn influence color characteristics, WHC and sensory aspects of meat (Bee et al., 2007; Ferguson and Warner, 2008).

In camel meat, water content, dry matter, ashes and proteins showed no significant variations during cold ageing (Tabite et al., 2018), nor under preslaughter stress (Barka et al., 2016). However, MDA contents increased significantly during the postmortem cold storage of camel meat (Tabite et al., 2018). Compared to raw meat, cooked meat levels of MDA were significantly very higher $7 \mathrm{~d}$ and $10 \mathrm{~d}$ postmortem.Barka et al. (2016) studied the effect of transport stress on lipid oxidation in 3 muscles (triceps, oblique and diaphragm) in the camel. 
The authors found that the level of MDA increased significantly in these muscles when the transport distance increased. The oxidation of oxymyoglobin and lipids, as well as microbial contaminations leads to discoloration, DL and the production of potentially toxic compounds (Aidani et al., 2014). The levels of MDA were continuously increased during cold storage of camel meat (Tabite et al., 2018) due to the generation of free short-chain fatty acids and unstable lipid hydroperoxide by microbial enzymatic hydrolysis (Gheisari et al., 2009). Lipid peroxidation is one of the main causes of deterioration in the quality of raw and cooked meat products of camel during refrigerated and frozen storage (Abdelhadi et al., 2013). Maqsoodet al. (2015) studied protein and lipid characterization of fresh camel meat during $9 \mathrm{~d}$ of refrigerated storage at $4^{\circ} \mathrm{C}$. They found that camel meat undergoes a lipid oxidation at a more pronounced level on the $3^{\text {rd }}$ day of cold storage, then a decrease in the peroxidation index, the $9^{\text {th }}$ day.

In raw and cooked meat of the camel, the content of 25-OH-D showed no significant variation during all postmortem ageing times. However, cooked meat showed a significant increase of 25-OH-D levels during ageing by comparison to raw meat. This difference could be explained by dehydration during cooking. The results observed here and those reported in previous investigations (El Khasmi et al., 2013; Bargaâ et al., 2015) showed that the camel meat may be a source of 25-OH-D. In both raw and cooked meat, 25-OH-D levels were negatively correlated with those of MDA, DL and CL, and those of MDA were positively correlated with DL and CL.

Beyond its established role in maintaining bone mass and mineral homeostasis, several findings of studies demonstrated multiple effects of vitamin D on skeletal muscle (Garcia et al., 2018). The presence of the vitamin D receptor (VDR) in most tissues of the body has just reinforced the argument in favor of its multiple functions (Walrand, 2016). The VDR has been found in muscle tissue in both animal models (Boland et al., 1985) and humans (Bischoff et al., 2001). Other authors have shown that VDR, expressed in skeletal muscle cells, specifically binds $1,25(\mathrm{OH})_{2} \mathrm{D}$. It should be noted that changes in vitamin D-induced intracellular calcium levels appear to modulate contraction and myofibrillar relaxation, thus affecting the contractile function of this tissue (Boland et al., 1985). The binding of $1,25(\mathrm{OH})_{2} \mathrm{D}$ to its receptor also promotes protein synthesis and affects cell growth in skeletal muscle (Salles et al., 2013).

Vitamin D status may impact skeletal muscle function, metabolism, hypertrophic growth, fibre composition and size (Ceglia et Harris 2013). In addition, previous studies in beef steers and pork reported that dietary vitamin D3 supplementation increased $\mathrm{pHu}$ and WHC, decreased DL, squeezable water and CL (Wilborn et al. 2004) and participated in antioxidant activity (Duffy et al. 2018). Expression of VDR varies in this tissue depending on age, sex, and diseases (Garcia et al., 2018). Furthermore, correlations between low circulating levels of vitamin D and muscle metabolism disorders were mentioned in muscle recovery, atrophy, sarcopenia and cachexia (Garcia et al., 2018).

Regarding the mechanisms concerning the effects of vitamin D on muscle mass and performance, some recent fundamental studies showed that vitamin D exerts molecular effects within the muscle cell. Precisely, a regulating action of vitamin $\mathrm{D}$ on calcium fluxes, mineral homeostasis and some signaling pathways controlling protein anabolism has been reported in muscle tissue (Aspray et al., 2014; SACN, 2016). The biological actions of vitamin D on muscle cell differentiation, metabolism and function may be multiple, acting through direct and indirect, genomic and nongenomic pathways (Rizzoli et al., 2014). Vitamin D has a pivotal role in the regulation and uptake of calcium in muscle cells, promoting protein synthesis and calcium and phosphate transport in muscle, which is important for muscle strength and contractile activity. Vitamin D appears to optimize the effect of dietary protein on skeletal muscle anabolism (Rizzoli et al., 2014). Both direct and indirect effects of vitamin D seem to play a role in muscle functionality by regulating calcium-dependent functions such as contraction, mitochondrial function and insulin sensitivity (Broe et al., 2007). Loss of muscle mass is related to vitamin D deficiency (O'Donnell et al., 2008; Richy et al., 2008). The mechanisms by which vitamin $\mathrm{D}$ affects muscle strength and function have not yet fully clarified but are likely mediated by the VDR and 1-alpha hydroxylase which are both expressed in muscle tissue (Robinson et al., 2018). Mechanistically, it has been suggested that 1,25-dihydroxyvitamin D binds to the nuclear VDR in muscle resulting in de novo protein synthesis (Bischoff-Ferrari, 2012). An anabolic effect of vitamin D in murine C2C12 myotubes through an increased insulin receptor and VDR mRNA expression was reported by Salles et al. (2013).

\section{Conclusion}

It could be concluded that cooking and cold storage of camel meat induced lipid peroxidation without significant alteration of 25-OH-D content. The meat levels of 25-OH-D were negatively correlated with those of MDA, DL and CL, and those of MDA were positively correlated with DL and CL. So, this metabolite may be implicated in antioxidant status and some quality parameters of the camel meat. Dietary vitamin D supplementation before slaughter could be of great help in improving the quality of camel meat 


\section{Acknowledgments}

The authors thank the President of urban municipalities of Casablanca and Dr. RachidAbouhafs the responsible for prefectural veterinary service of Casablanca, to carry out this work.

\section{References}

AOAC. 2000. Association of Official Analytical Chemists. Official methods of analysis. Gaithersburg, MD, USA.

Abdelhadi, O.M.A., Babiker, S.A., Hocquette, J.F., Picard, B., Durand, D. and Faye, B. 2013. Effect of Ageing on Meat Quality of the One Humped Camel (Camelusdromedarius). Emirate Journal of Food and Agriculture 25(2). 150-158.

Aidani, E., Aghamohammadi, B., Akbarian, M., Morshedi, A., Hadidi, M., Ghasemkhani, N. and Akbarian, A. 2014. Effect of Chilling, Freezing and Thawing on Meat Quality: A Review. International Journal of Biosciences5(4). 159-169.

Aspray, T.J., Bowring, C., Fraser, W., Gittoes, N., Javaid, M.K., Macdonald, H., Patel, S., Selby, P., Tanna, N. and Francis, R.M. 2014. National Osteoporosis Society vitamin D guideline summary. Age and ageing 43(5). 592595.

Bargaâ, R.., El Khasmi, M., Farh, M., Tahri, E.H., El Abbadi, N., Abouhafs, R. and Faye, B. 2015. Seasonal variation of 25-hydroxyvitamin D3 levels in meat of Moroccan one humped dromedary camels (Camelusdromedarius). In: Proceedingsof the 4thConference of the International Society of Camelid Research and Development: ISOCARD 2015. Editor in chief Konuspayeva, G. Al-Farabi Kazakh National University - Almaty, Kazakhstan. 488 c. ISSN 1999-3951: ISOCARD, pp 180-182.

Barka, K., Farh, M., Riad, F., Tahri, E. H., Belhouari, A. and El Khasmi, M. 2016. Impact of transport distance on some stress biomarkers levels in Camel meat. MOJ Food Processing \& Technology 2(4). 130-134.

Bee, G., Anderson, A.L., Lonergan, S.M. and Huff-Lonergan, E. 2007. Rate and extent of pH decline affect proteolysis of cytoskeletal proteins and water holding capacity in pork. Meat Science 76(2). 359-365.

Bischoff, H.A., Borchers, M., Gudat, F., Duermueller, U., Theiler, R., Stahelin, H.B. and Dick, W. 2001. In situ detection of 1,25-dihydroxyvitamin $\mathrm{D}_{3}$ receptor in human skeletal muscle tissue. The Histochemical Journal 33(1). 19-24.

Bischoff-Ferrari, H.A. 2012. Relevance of vitamin D in muscle health. Reviews in Endocrine and Metabolic Disorders 13(1). 71-77.

Boland, R., Norman, A., Ritz, E. and Hasselbach, W. 1985. Presence of a 1,25-dihydroxyvitamin $\mathrm{D}_{3}$ receptor in chick skeletal muscle myoblasts. Biochemical and Biophysical Research Communications 128(1). 305-311.

Broe, K.E., Chen, T.C., Weinberg, J, Bischoff-Ferrari, H.A., Holick, M.F. and Kiel, D.P. 2007. A higher dose of vitamin $d$ reduces the risk of falls in nursing home residents: A randomized, multiple-dose study. Journal of the American Geriatrics Society 55(2). 234-239.

Ceglia, L. and Harris, S.S. 2013. Vitamin D and Its Role in Skeletal Muscle. Calcified Tissue International 92(2). 151162.

Duffy, S.K., Kelly, A.K., Rajauria, G., Jakobsen, J., Clarke, L.C., Monahan, F.J., Dowling, K.G., Hull, G., Galvin, K., Cashman, K.D., Hayes, A. and O’Doherty, J.V. 2018. The Use of Synthetic and Natural Vitamin D Sources in Pig Diets to Improve Meat Quality and Vitamin D Content. Meat Science 143: 60-68.

El Khasmi, M., Bergaâ, R., Riad, F., Safwate, A., Tahri, E.H., Farh, M., El Abbadi, N., Abouhafs, R. and Faye, B. 2013. Meat levels of 25-hydroxyvitamin D3 in Moroccan one-humped dromedary camels (Camelusdromedarius). Emirates Journal of Food and Agriculture25(4). 267-273.

El Khasmi, M., Chakir, Y., Bargaâ, R., Barka, K., Lektib, I., El Abbadi, N., Belhouari, A. and Faye, B. 2015. Impact of transport distance on stress biomarkers levels in dromedary camel (Camelusdromedarius). Emirates Journal of Food and Agriculture 27(6). 507-512.

Ferguson, D.M. and Warner, R.D. 2008. Have we underestimated the impact of pre-slaughter stress on meat quality in ruminants? Meat Science80. 12-19.

Garcia, M., Seelaender, M., Sotiropoulos, A., Coletti, D. and Lancha, A.H.Jr. 2018. Vitamin D, muscle recovery, sarcopenia, cachexia, and muscle atrophy. Nutrition 7(60). 66-69.

Gheisari, H.R., Aminlari, M. and Shekarforoush, S.H. 2009. A Comparative Study of the Biochemical and Functional Properties of Camel and Cattle Meat during Frozen Storage. VeterinarskiArhiv79(1). 51-68.

Honikel, K.O. 1998. Reference Methods for the Assessment of Physical Characteristics of Meat. Meat Science 49(4). 447-457. 
Hur, S.J., Ye, B.W., Lee, J.L., Ha, Y.L., Park, G.B. and Joo, S.T. 2004. Effects of conjugated linoleic acid on color and lipid oxidation of beef patties during cold storage. Meat Science 66(4). 771-775.

Kadim, I.T., Mahgoub, O., Al-Marzooqi, W., Al-Zadijali, S., Annamalai, K. and Mansour, M.H. 2006. Effects of Age on Composition and Quality of Muscle LongissimusThoracisof the Omani Arabian Camel (Camelus dromedaries). Meat Science 73(4). 619-625.

Kanner, J. 2007. Dietary Advanced Lipid Oxidation Endproducts Are Risk Factors to Human Health. Molecular Nutrition \& Food Research 51(9). 1094-1101.

Kober, A., Bari, M.S., Rakib, M.R. and Ali, M.S. 2014. Injuries of cattle and buffaloes during transportation and slaughter at Chittagong city corporation of Bangladesh. Bangladesh. Journal of Animal Science 43(1). 74-77.

Lemrhamed, A., Farh, M., Riad, F., El Abbadi, N., Tahri, E.H., Belhouari, A., Faye, B. and El Khasmi, M. 2018. Evaluation of stress responses induced by the loading density in dromedary camel (Camelusdromedarius). Emirates Journal of Food and Agriculture 30(9). 803-808.

Lemrhamed A., Tabite, R., Farh, M., Riad, F., El Abbadi, N., Tahri, E.H., Faye, B. and El Khasmi, M. 2019a. Evaluation of preslaughter stress responses during waiting time at lairage in the dromedary camel (Camelusdromedarius). JCPR.

Lemrhamed, A., Tabite, R., El Abbadi, N., El khasmi, M. and Faye, B. 2019b. Evaluation of slaughter stress responses in the dromedary camel. International Journal of Livestock Research 9(8). 78-90.

Maqsood, S., Abushelaib, A., Manheem, K. and Kadim, I.T. 2015. Characterisation of the Lipid and Protein Fraction of Fresh Camel Meat and the Associated Changes during Refrigerated Storage. Journal of Food Composition and Analysis 41: 212-220.

Maqsood, S. and Benjakul, S. 2011. Retardation of Haemoglobin-Mediated Lipid Oxidation of Asian Sea Bass Muscle by Tannic Acid during Iced Storage. Food Chemistry 124(3). 1056-1062.

O'Donnell, S., Moher, D., Thomas, K., Hanley, D.A. and Cranney, A. 2008. Systematic review of the benefits and harms of calcitriol and alfacalcidol for fractures and falls. Journal and Bone Mineral Metabolism 26(6). 531542.

Offer, G. and Knight, P. 1988. The Structural Basis of Water-Holding in Meat: General Principles and Water Uptake in Meat Processing. In Developments in Meat Science. New York: Elsevier Applied Science Publishing Co., Inc. pp 63-171.

Ohkawa, H., Ohishi, N. and Yagi, K. 1979. Assay for lipid peroxides in animal tissues by thiobarbituric acid reaction. Analytical Biochemistry 95(2). 351-358.

Pohja, M.S. and Niinivaara, F.P. 1957. Die Bestimmung der Wasserbindung des Fleischesmittels der Konstantdrückmethode. Fleischwirtschaft 9. 193-195.

Richy, F., Dukas, L. and Schacht, E. 2008. Differential effects of D-hormone analogs and native vitamin D on the risk of falls: A comparative meta-analysis. Calcified Tissue International 82(2). 102-107.

Rizzoli, R., Stevenson, J.C., Bauer, J.M., van Loon, L.J., Walrand, S., Kanis, J.A., Cooper, C., Brandi, M.L., DiezPerez, A., Reginster, J.Y. 2014. The role of dietary protein and vitamin D in maintaining musculoskeletal health in postmenopausal women: A consensus statement from the European Society for Clinical and Economic Aspects of Osteoporosis and Osteoarthritis (ESCEO). Maturitas 79(1). 122-132.

Robinson, S.M., Reginster, J.Y., Rizzoli, R., Shaw, S.C., Kanis, J.A., Bautmans, I., Bischoff-Ferrari, H., Bruyere, O., Cesari, M., Dawson-Hughes, B. et al. 2018. Does nutrition play a role in the prevention and management of sarcopenia? Clinical Nutrition 37(4). 1121-1132.

SACN. 2016. Special Advisory Committee On Nutrition. Vitamin D and Health UK.

Salles, J., Chanet, A., Giraudet, C., Patrac, V., Pierre, P., Jourdan, M., Luiking, Y.C., Verlaan, S., Migne, C., Boirie, Y. and Walrand S. 2013. 1,25(OH) $)_{2}$-VWitamin D3 enhances the stimulating effect of leucine and insulin on protein synthesis rate through Akt/PKB and mTOR mediated pathways in murine C2C12 skeletal myotubes. Molecular Nutrition \& Food Research 57(12). 2137-2146.

Salmi, B., Trefan, L., Bünger, L., Doeschl-Wilson, A., Bidanel, J.P., Terlouw, C. and Larzul., C. 2012. Bayesian metaanalysis of the effect of fasting, transport and lairage times on four attributes of pork meat quality. Meat Science 90(3). 584-598.

SAS. 2005. Statistical Analysis System Package. Cary, NC: SAS Institute, Inc.

Swanson, J.C. and Morrow-Tesch, J. 2001. Cattle transport: historical, research, and future perspectives. Journal of Animal Science 79(Suppl. E). E102-E109.

Tabite, R., Barka, K., Farh, M., Riad, F., El Abbadi, N., Tahri, E.H., Belhouari, A., Faye, B. and El Khasmi, M. 2018. Effect of postmortem ageing on quality parameters, contents of proteins, lipids and 25-hydroxyvitamin D, and oxidative stability in the camel meat during cold storage. Journal of Agricultural Sience and Technology A. 8(5). 323-332. 
Teke, B., Akdag, F., Ekiz, B. and Ugurlu, M. 2014. Effects of different lairage times after long distance transportation on carcass and meat quality characteristics of Hungarian Simmental bulls. Meat Science 96(1). 224-229.

Terlouw, E.M.C. and Rybarzcyk, P. 2008. Explaining and predicting differences in meat quality through stress reactions at slaughter: The case of Large White and Duroc pigs. Meat Science 79(4). 795-805.

Walrand, S. 2016. Les effetsmusculaires de la vitamine D. GériatrieetPsychologieNeuropsychiatrie du Vieillissement14(2). 127-134.

Wilborn, B.S., Kerth, C.R., Owsley, W.F., Jones, W.R. and Frobish, L.T. 2004. Improving pork quality by feeding supranutritional concentrations of vitamin D3. Journal of Animal Science82(1). 218-224. 